\title{
POLITICAL MEDIA MEMES' PERSUASION AND FUNCTIONING IN SOCIAL MEDIA
}

\author{
I.S. Kuznetsov, Ya.V. Soldatkina \\ Moscow State Pedagogical University \\ Malaya Pirogovskaya, 1, Moscow, Russia 119991
}

The purpose of the article is to analyze the political media memes' functioning, their effects and persuasion, to classify them and to describe their structure. In this study finding authors describe the actual persuasion of media memes in contemporary Russian society. Media memes have got a clear structure via they could spread in social media. This structure also allows to classify media memes for better understanding their functioning and general message, authors rank political media memes illustrating the ones of recent US presidential elections. These units' successful using as a format of media effect and their replication in media can depend on our ways of persuasion, on neurological and psychological basis of information virality. In a nutshell, political media memes couldn't be considered as humor units only, but also as a format of media impact, an effective tool of media discourse, propaganda and political agitation during election season.

Key words: media meme, social media, media effects, political discourse, information virality

Contemporary information processing and their transformation make the reality to which the media and the audience adjust. Some formats are widely used in social media transforming and adapting annually in accordance with changing reality despite of the fact that they appeared about a decade ago and they haven't had a theoretical basis describing their functioning. The one of these formats is political media meme used in social media as a tool of political discourse and an information and cultural unit.

When RuNet users talk about media memes they usually mean one of their types named creolized text that is an image with some verbal component (comics, collage, demotivators etc.). But the term "media meme" as a cultural and information unit includes a wide range of various forms and could be defined as a type of memes spreading in mass media as a form of information transfer and a tool of audience impact. The term "meme" originated with Richard Dawkins' "The Selfish Gene" (1976). Dawkins said that meme is a new replicator, a unit of cultural transmission, or a unit of imitation which propagates itself in the meme pool by leaping from brain to brain via a process which, in the broad sense, can be called imitation [1]. A lot of scientists considered that his term is overgeneralized, therefore they try to define the word "meme" themselves, basing on a psychology, sociology, biology, neurobiology, journalism etc.

As to political media memes, we can state that these units have got a clear structure allowing their spreading in mass media, social media and in messages during interpersonal communication. In our view, this structure includes two basic elements: 
1. Appearance. An "external shell” which focuses audience's attention on media meme and allows its replication in network. Media meme can spread as a creolized text, hashtag, verbal structures, words and phrases, videos, audios etc. Wide range of media memes' various forms is described below in authors' classification.

2. Semantic core. Complex of meanings and senses of the unit, its general message which impacts on audience. The element that makes media meme one of the most effective formats in political discourse and provides its influence on public opinion.

Douglas Rushkoff, an American media theorist, described similar units in his "Media Virus: Hidden Agendas in Popular Culture" (1996) [2]. He called them "media viruses" and he compared their structure with the viral one. Rushkoff said that media virus's appearance is like a capsid, the protein shell of bacteriophage, and its semantic core is like a DNA inside the capsid. According to the media theorist, media virus can infect human brain with unwanted information as bacteriophage does. Also Douglas Rushkoff states that media virus's structure (media virus, in this context, refers to both media viruses and the media memes as the similar units) is similar to the Trojan Horse. He said that Trojan Horse is the units' appearance and Greeks inside of the Horse are like the semantic core. According to him, it's evident that this kind of impact is nothing but a negative one.

In our view, the knowledge of the similar formats' functioning allows audience to avoid unwanted influence by media. While Russian users are still considering media memes as an entertainment content, the units are being successfully used in traditional media (TV, broadcast, press) and in new media (social media, websites, blogs, online newspapers etc.). Understanding of the impact techniques used by media memes allows users to find information which is laid in the "entertainment content", to prevent attempts to manipulate and to understand the risk of being manageable in daily life even though not being media audiences.

For better understanding of media memes' functioning these units should be classified and the using of these viral formats with their complexes of meanings and senses should be analyzed. The result of our research is the political media memes' classification based on scientific articles written by contemporary researchers from Russian Federation, Ukraine, Poland, France, UK, USA, Germany etc. [3]. This document says about just two of several classification criteria - media meme's appearance and their semantic core. There are four types of media memes' appearance:

1. Verbal media memes. Texts, words, phrases, slang and lingo, key words, hashtags etc. Examples: Clintongate; Love Trumps Hate; Make America Great Again; Au nom du peuple; \#ImWithHer; \#OscarIsSoWhite; Black Lives Matter; \#SadMelania etc.

2. Audial media memes. Songs, melodies and sound that are used in political discourse somehow. Examples: Vladimir Putin sings "Blueberry Hill" during the benefit concert in Saint Petersburg December 2010; protest songs of different countries, starting with French "La Marsellaise" and Italian "Bella, ciao" and ending with Sixto Rodrigues's and Lyapis Trubetskoy band's songs that were inspiring protest movements in South Africa in final years of apartheid and in Ukraine during Euromaidan respectively.

3. Visual media memes. Images, collages, posters, photoshop contests, comics, photos, pictures, caricatures etc. Examples: Pepe the Frog; comparative series "Ted Cruz is the Zodiac Killer" and "Donald Trump is Biff Tannen"; Michelle Obama's and Melania 
Trump's photos from inauguration of Donald Trump; caricature on Vladimir Putin riding the horse/bear/shark etc. forced in US media etc.

\section{Hybrid media memes}

4.1. Creolized text. Memes with two parts, verbal and nonverbal. Collages, demotivators, images with "funny" phrases etc. Examples: series "The Russian hackers did it"; photo of US President Donald Trump and Vice President Michael "Mike" Pence forced in Russian social media with the short inscription "Did you ever think that US will be ruled by Donald and Mickey" etc.

4.2. Audiovisual media memes. Videos, coubs, clips, vines etc. Examples: Donald Trump mocking reporter Serge Kovalevski; Russian liberal-democrats' leader Vladimir Zhirinovsky laughing "devil laugh" during "Voskresniy Vecher" (late night political talk show by Rossiya-1 TV-channel) etc.

Another one media memes' classification criteria is their semantic core, its general goal actually. The semantic core's general goal is what media meme was created for and what it's used for in mass media and social networks. According to Douglas Rushkoff, some people or some power is always behind every information unit in which replication they're profitable. These powers which are usually political or business elite, Rushkoff said, sooner or later will use every viral unit as a leverage. Even if a media meme wasn't created for the specific purpose and its generation was spontaneous (it means media meme is nothing but an audience's reaction to some event), it could most likely be used by political or business elite as a leverage, he said. According to the Rushkoff's theory also to his colleagues' (Susan Blackmore, Richard Dawkins, Daniel Dennett, R mi Sussan etc.) researches, we can divide general goals of media memes' semantic cores into two groups:

1. Memes-aggressors. The media meme's general message is destructive, its goal is to discredit an idea, a political program, politics' or/and media persons' authority, to destroy the status quo. Examples: Meryl Streep's, Alec Baldwin's and Robert de Niro's speeches against president-elect Donald Trump January 2017.

2. Memes-protectors. The media meme's general goal is to keep the status quo, to enhance a person's of a political elite's authority, to protect a state ideology, an elite. Examples: Make America Great Again and Au Nom du Peuple are the election slogans of Donald Trump and Marine Le Pen (France) used as a motivation slogan to support the candidates.

Now when we describe existing forms and general goal of political media memes, we should tell about their functioning. The reason of media meme's effectiveness is in how we perceive them and how our brain responds to the viral information. We state that people perceive media memes and their messages with the peripheral route according to the Richard Petty's elaboration likelihood model (ELM) of persuasion. It allows to bet on wide audience, because with this route they are more likely to rely on general impressions, mood, early parts of the message, not on significant cognitive efforts and deep analysis of the message. But the peripheral route of persuasion isn't so effective when it comes to long-term changes in attitudes, and the targets' effect is weak and shortterm with the peripheral route [4]. In other words, we can say that media meme being persuaded with peripheral route could impact on audience in the short term and without any arguments, but its influence is also short-term and unsustainable. But because of 
rapid growth of political media memes and their permanent transformation the number of units makes up for short-term impact of the format - the quantity makes up for the low quality of the influence. Entertainment function of media memes plays the big role too, because audience often perceives media memes as a part of interpersonal communication or a humor unit of contemporary online-culture.

Another one reason of media memes' effective replication may lie in neurological basis of information virality. In 2013 UCLA psychologists published the study findings where they said that they had mapped the brain regions associated with "contagious" information [5]. During their experiment MRI showed high activity of focus-group members' temporoparietal junction (TPJ) - an area of the brain where the temporal and parietal lobes meet - as the reaction on viral information. TPJ was especially active when the person saw "buzz" - viral information and ideas that could spread and sell more effectively. Psychologist called this the "salesperson effect". We can say that our TRJ's activity level is high when we persuade media memes, because they're viral units. UCLA psychologists state that the discovery the "contagious" ideas' neurological basis could be used by informational campaigns for spromoting healthy lives. But there are no guarantees that this discovery couldn't be used as a tool of PR, brand promotion, agitation and propaganda.

Political media memes can spread autonomously (as social media posts, hashtags, media texts etc.) and as an attachment, as a part of media text in social media. Political media meme may be used as a frame if it is published in the network as a part of journalistic material (video or article). Frame is the element of a hypertext forming the message context. In other words, media memes included in a text concentrate audiences' attention on one or another aspect of message, form the "right" perception. According to framing theory, these frames may focus audience's attention, lead users to something, form their way of thinking [6].

Also there are, according to several researchers, the processes or events that might be media memes generators - "meme magnets" [7]. Examples of these "magnets" are War in Donbass (2014 - our days), US election campaign (2015-2016), Donald Trump's victory, sanctions against Russia (2014 - our days) etc. These and other political processing is resonance and might be interesting for the audience that is the reason of generation and replication of numbers of media memes.

However, without taking into account "meme magnets", last years the number and the diversity of media memes have grown exponentially. Funny images was used in social networks for interpersonal communication, expressing emotions and entertainment, now they became an active tool of propaganda, information transfer, protest, expression of political views, even of political agitation. Western researches stopped considering media memes as entertainment content a long time ago, and then after the US elections 20152016 called media meme "the new king of political communications" at all.

Some US universities' researches are publishing study findings focused on media meme as the way of impact on audience, German, French, East-European researches are doing the same. Some French media experts are creating the website where they are publishing an exposure of some effects techniques, hoaxes and media memes replicated in social media. This process is the result of media memes' replication, its popularity and effectiveness not only as entertainment content. 
To summarize, we state that political media memes used both in social media and in traditional media haven't been "something funny" for long time. A lot of media memes not only form the new online and offline culture, but also they are an effective tool of media effects, agitation, propaganda and political discourse. Media memes having got a clear structure could be used as viral forms that replicate and have an effective and shortterm impact on public opinion. Their effectiveness could be related to their neurological and psychological perception features, but the researches in this area are continuing. Nevertheless various political powers and players use media memes reaching their targets with the least effort and cost. As for recipient, he could be impacted not only by mass media, but also by social networks' news feeds, online-communities and even by other users. Knowledge of their generation's principles, replication, functioning and the ways of their effect could help users to prevent unwanted influence and to be more careful scrolling social networks.

(C) Kuznetsov I.S., Soldatkina Ya.V., 2017

\section{REFERENCES}

[1] Dawkins R. "The Selfish Gene”. Oxford: Oxford University Press, 1989. 192 p.

[2] Rushkoff D. "Media Virus: Hidden Agendas in Popular Culture". Ballantine Books, NY, 1996.

[3] Kuznetsov I.S. "Teoreticheskaya klassifilatsiya politicheskikh mediamemov" ["The political media memes' theoretical classification"] // "Put' k idealu": sbornik nauchnykh trudov, posvyaschennykh yubileyu doktora filololgicheskikh nauk, professora V.A. Slavinoy. Moscow, 2016. P. 151-158.

[4] Bryant J., Thompson S. "Fundamentals of Media Effects". McGraw-Hill, NY, 2002.

[5] Wolpert S. "How the brain creates the 'buzz' that helps ideas spread" // UCLA. URL: http:// newsroom.ucla.edu/releases/how-the-brain-creates-buzz-247204 (accessed 05.03.2017).

[6] Mass Communication Theory // University of South Florida. URL: https://masscommtheory. com (accessed 05.03.2017).

[7] Wiggins B. "How the Russia-Ukraine crisis became a magnet for memes" // The Conversation. URL: http://theconversation.com/how-the-russia-ukraine-crisis-became-a-magnet-formemes-31199 (accessed 05.03.2017).

\section{Article history:}

Received: 13 February 2017

Revised:15 March 2017

Accepted: 3 April 2017

\section{For citation:}

Kuznetsov I.S., Soldatkina Ya.V. (2017) Political media memes' persuasion and functioning in social media. RUDN Journal of Studies in Literature and Journalism, 22 (2), 333-339.

\section{Bio Note:}

Kuznetsov Ivan Sergeevich, MBA student, Institute of Journalism, Communications and Media education, Moscow Pedagogical State uviversity.

Contacts: e-mail: kuznetsov0803@mail.ru

Soldatkina Yanina Victorovna, Doctor of philology, professor of Department of Russian Literature, Institute of Philology, Moscow Pedagogical State uviversity.

Conatcts: e-mail: yav.soldatkina@mpgu.edu 


\title{
ВОСПРИЯТИЕ И ФУНКЦИОНИРОВАНИЕ ПОЛИТИЧЕСКИХ МЕДИАПРИЕМОВ В СОЦИАЛЬНЫХ МЕДИА
}

\author{
И.С. Кузнецов, Я.В. Солдаткина \\ Московский педагогический государственный университет \\ Малая Пироговская, 1, Москва, Россия, 119991
}

Цель представленной статьи - анализ функционирования политических медиамемов, особенности их воздействия и восприятия аудиторией, их классификация и описание структуры виральных единиц. В ходе проведенного исследования авторы анализируют функционирование и способы влияния медиамемов в российском сегменте интернета. Современные медиамемы имеют четкую структуру, позволяющую им активно реплицироваться в социальных медиа. Данная структура также позволяет исследователю классифицировать виральные единицы для лучшего понимания принципов их функционирования и основного месседжа. Авторы приводят собственную классификацию политических медиамемов, подкрепляя актуальными примерами последней президентской кампании в США. Успешные репликация и использование медиамемов в качестве инструмента воздействия на аудиторию могут зависеть от неврологических и психологических основ восприятия виральной информации. Сегодня политические медиамемы используются не только как единицы рекреативной сферы, но и как эффективный инструмент воздействия на аудиторию, пропаганды и политической агитации в ходе предвыборных кампаний.

Ключевые слова: медиамем, социальные медиа, политический дискурс, виральная информация, воздействие медиа

\section{СПИСОК ЛИТЕРАТУРЫ}

[1] Dawkins $R$. The Selfish Gene. Oxford: Oxford University Press, 1989. 192 c.

[2] Rushkoff D. Media Virus: Hidden Agendas in Popular Culture. Ballantine Books, NY, 1996.

[3] Кузнецов И.С. Теоретическая классификация политических медиамемов // Путь к идеалу: сб. научн. тр., посвященных юбилею доктора филологических наук, профессора В.А. Славиной. М., 2016. С. 151-158.

[4] Bryant J., Thompson S. Fundamentals of Media Effects. McGraw-Hill, NY, 2002.

[5] Wolpert $S$. "How the brain creates the 'buzz' that helps ideas spread" // UCLA. URL: http:// newsroom.ucla.edu/releases/how-the-brain-creates-buzz-247204 (дата обращения: 05.03.2017).

[6] Mass Communication Theory // University of South Florida. URL: https://masscommtheory. com (дата обращения: 05.03.2017).

[7] Wiggins B. "How the Russia-Ukraine crisis became a magnet for memes" // The Conversation. URL: http://theconversation.com/how-the-russia-ukraine-crisis-became-a-magnet-formemes-31199 (дата обращения: 05.03.2017).

\section{История статьи:}

Дата поступления в редакцию: 13 февраля 2017

Дата принятия к печати: 3 апреля 2017

\section{Для цитирования:}

Кузнецов И.С., Солдаткина Я.В. Восприятие и функционирование политических медиаприемов в социальных медиа // Вестник Российского университета дружбы народов. Серия: Литературоведение. Журналистика. 2017. Т. 22. № 2. С. 333-339. 
Kuznetsov I.S., Soldatkina Ya.V. RUDN Journal of Studies in Literature and Journalism, 2017, 22 (2), 333-339

\section{Сведения об авторах:}

Кузнецов Иван Сергеевич, магистрант Института журналистики, коммуникаций и медиаобразования Московского педагогического государственного университета.

Контактная информация: e-mail: kuznetsov0803@mail.ru

Солдаткина Янина Викторовна, доктор филологических наук, профессор кафедры русской литературы Института филологии Московского педагогического университета.

Контактная информация: e-mail: yav.soldatkina@mpgu.edu 